\title{
Origin, Distribution, Impact and Management of Water Hyacinth (Eichhornia crassipes (Martius) Solm): A Review
}

\author{
Nagassa Dechassa \\ Ethiopian Institute of Agricultural Research, Ambo Agricultural Research Centre, Ambo, Ethiopia
}

\begin{abstract}
Water hyacinth is one of the world's worst invasive weeds. It is native to South America and extremely invaded many tropical and subtropical countries of all the continents. The ability to produce via runners, stolons and seed; fast growth; seed persistence in the soil and its beautiful flower facilitates the spread of the weed from region to regions from time to time. Blockage of irrigation, electric power generation, fish production and water way transportation are the major economic impacts of the weed. Manual and mechanical removal of water hyacinth in small areas at early time is effective in controlling the weed for short period of time. Use of biological control agents; arthropods (Neochetina brunchi, Neochetina eichhorniae, Niphograpta albiguttalis and Orthogalumna terebrantis) and parasitic fungi (Cercospora rodmanii, Alternaria alternata and Alternaria eichhorniae) play a role in controlling the weed. In addition Chemical control with 2, 4-D dimethyl amine, glyphosphate and acetic acid are effective to control water hyacinth in extreme cases. Integrated use of herbicidal and mechanical control measures is effective in control, economically safe and environmentally friendly than a single control measures.
\end{abstract}

Keywords: Alternaria, Aquatic weed, Invasive weed, Neochetina, Weed control, Weevils

DOI: $10.7176 / \mathrm{JEES} / 10-10-02$

Publication date:October $31^{\text {st }} 2020$

\section{INTRODUCTION}

Water hyacinth (Eichhornia crassipes) is a serious, persistent, aquatic, free-floating and perennial weed that is native to South America. It is considered the most damaging Aquatic weed in the world because of its very fast growth rate and its adaptation to a wide range of nutrient and environmental conditions (WHO, 1997). The International Union for Conservation of Nature (IUCN) has identified that this weed is one of the 100 most aggressive invasive species (Tellez et al., 2008) and recognized as one of the top 10 worst weeds in the world (Patel, 2012). It is one of the world's worst invasive weed which invades many tropical and sub-tropical regions around the world. People use the weed as an ornamental plant due to its beautiful flowers and facilitate the spread of the weed from infested region to an infested region.

The plant displaces native vegetation on water bodies due to its rapid growth during the rainy season. It is one of the fastest growing plants whose population growth is doubled in size with in just two weeks (Penfound and Earle, 1948). Its primary means of reproduction is by way of runners and stolons, which eventually form daughter plants. It also produces large quantities of seeds that are viable for up to 30 years. These special reproduction features of the weed created difficulty in management and control of the weed. Therefore, the objective of this paper is to review the origin, distribution, impact and management options of water hyacinth.

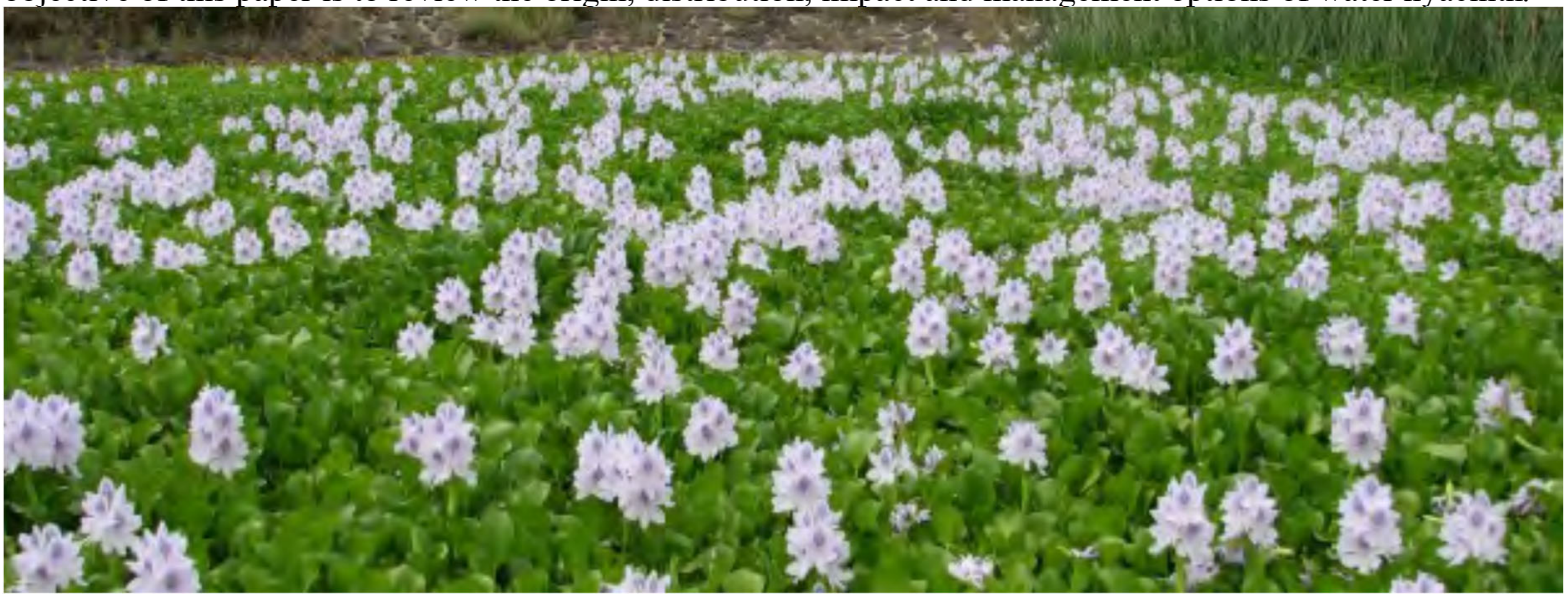

Figure 1. Water hyacinth with its beautiful flowers

\section{BODY OF THE TEXT}

\subsection{Origin and Distribution of Water Hyacinth}

Water Hyacinth is native to South America and extremely invaded many tropical and subtropical countries of Latin America and the Caribbean, Africa, Southeast Asia and the Pacific. Due to its beautiful and attractive flowers 
people used water hyacinth weed as an ornamental plant and spread it from place to place. However, more important explanations for the continental spread of the weed include its capacity to quickly multiply when away from its natural enemies in South America. Currently, the weed is distributed through North America, South America, Eastern Africa and Asia.

The Water hyacinth was introduced from its native home in South America to various countries by wellmeaning people as an ornamental plant; to the United State in the 1880's. It was introduced in Egypt in about 1879. It spread to the Congo, the Nile and Lake Victoria in 1950's. It introduced in Asia in 1888 and to Australia around 1890. Water hyacinth has invaded various countries of West Africa at various times. In Africa the weed first reported in 1957 in Republic of Congo. However, most of the invasions have occurred since the early 1980s. The outbreak of this invasive weed was reported in Benin, Ghana, Nigeria, Burkina Faso, Mali, Niger, Benin, Egypt, Ethiopia, Zimbabwe, Mozambique, Tanzania, Zambia, Malawi, Kenya, Uganda, Rwanda and Burundi.

\subsection{Impact of Water Hyacinth}

Interference of navigation, irrigation, electric power generation and money lost to manage water hyacinth are the major economic impacts caused by the invasion of the weed. Also the dense mats of the weed can provide ideal mosquito breeding habitats (Julien, 2001). Obviously, water hyacinth has put most traders and fishermen out of business, thereby subjecting their families to untold economic hardship. It causes the worst effect on people in the developing countries who depend on fisheries for their diet and livelihood (Hill et al., 1997). The occurrence of high prolific water hyacinth in water ways has greatly affected the lives of the riverine people in many developing countries of Africa. The thick mat of Water hyacinth trapped seven commercial boats transporting 500 traders and goods in Nigeria (Uka, 2008).

Mats block light from penetrating water bodies, which induces changes in the flora and fauna underneath, sometimes hindering fish production and resulting in unemployment and diminished incomes and food for riparian communities due to the fact that local plants and animals lose their habitats and the quality of drinking, cooking and washing water deteriorates. There are even reports of village people dying from the problems of heavy water hyacinth infestation; 1) People have died from starvation because they could not reach food sources; 2) Bites of venomous snakes hiding in water hyacinth mats; 3) Attacks by crocodiles taking shelter in water hyacinth mats; 4) Diseases carried by mosquitoes (malaria) or snails (bilharzia) that breed in water hyacinth environments; and 5) Fatigue from pushing canoes through clogged waterways (Navarro and Phiri, 2000).

\subsection{Management of Water Hyacinth}

Control of water hyacinth using conventional methods such as manual, mechanical removal, chemical and biological controls has been mostly employed globally.

\subsubsection{Physical Control}

Mechanical removal of water hyacinth is the best short term solution in controlling the proliferation of the weed in small areas. Land based 'clamshell' bucket cranes, draglines or booms and water based machinery such as mowers, dredges and barges are suitable in removing water hyacinth from water. However mechanical removal of water hyacinth is costly and suitable for small areas. Many of these techniques require the support of a fleet of water and land-based vehicles for transporting the large quantities of water hyacinth which is removed. 


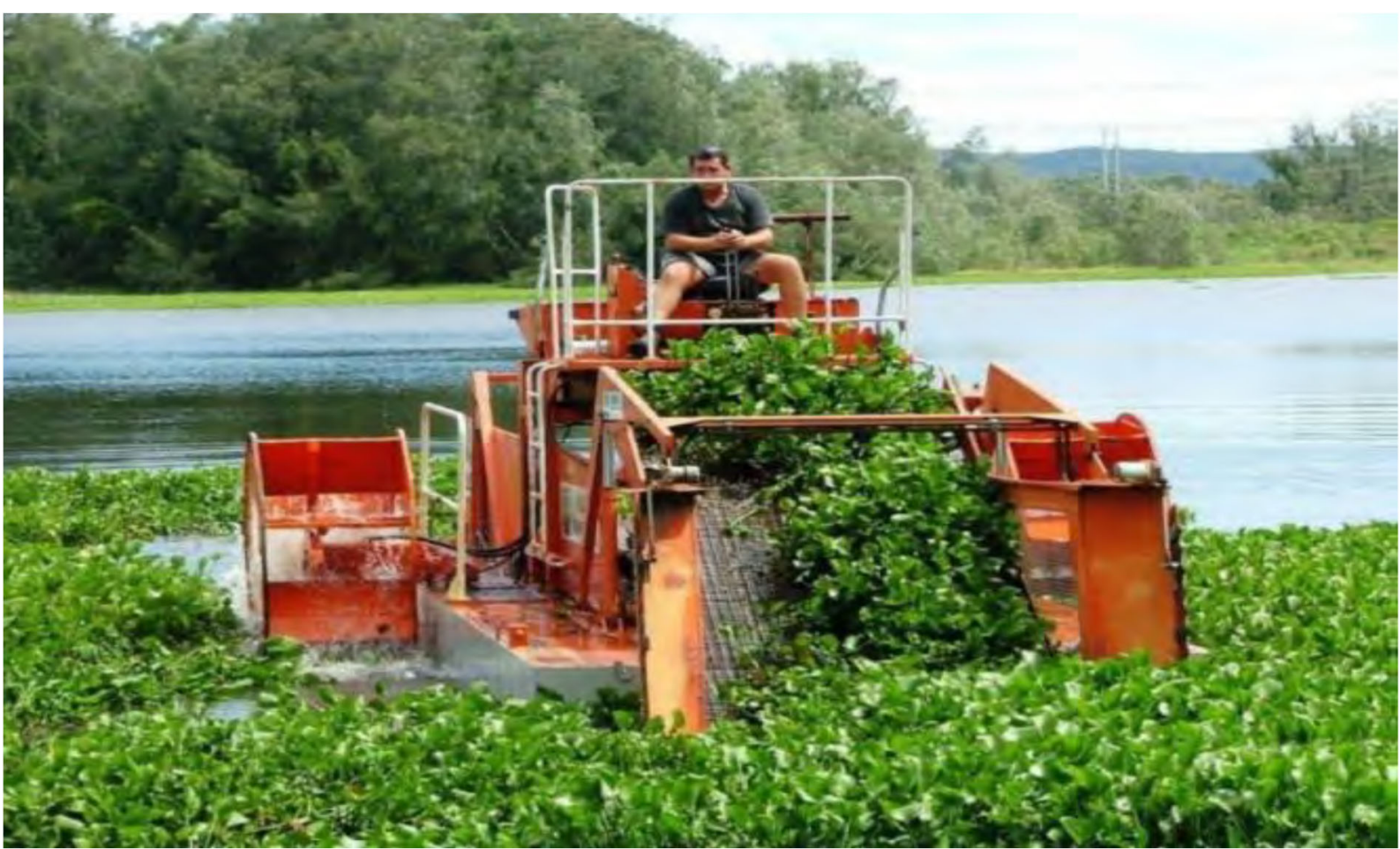

Figure 2. Mechanical removal of water hyacinth.

Manual removal of water hyacinth is also suitable for extremely small areas but ineffective for large infestations control. Early control attempts concentrated on removing the plant from water with hand or instrument like pitchforks, then dumping the accumulated mass on land to die. However, it is difficult, labor intensive work and in some areas there is serious health risks associated with the workers (crocodiles, hippopotamus, snakes, mosquitoes and bilharzia). Transportation of the harvested weed is also costly, because it has such high water content. Chopping can reduce the volume and the water content.

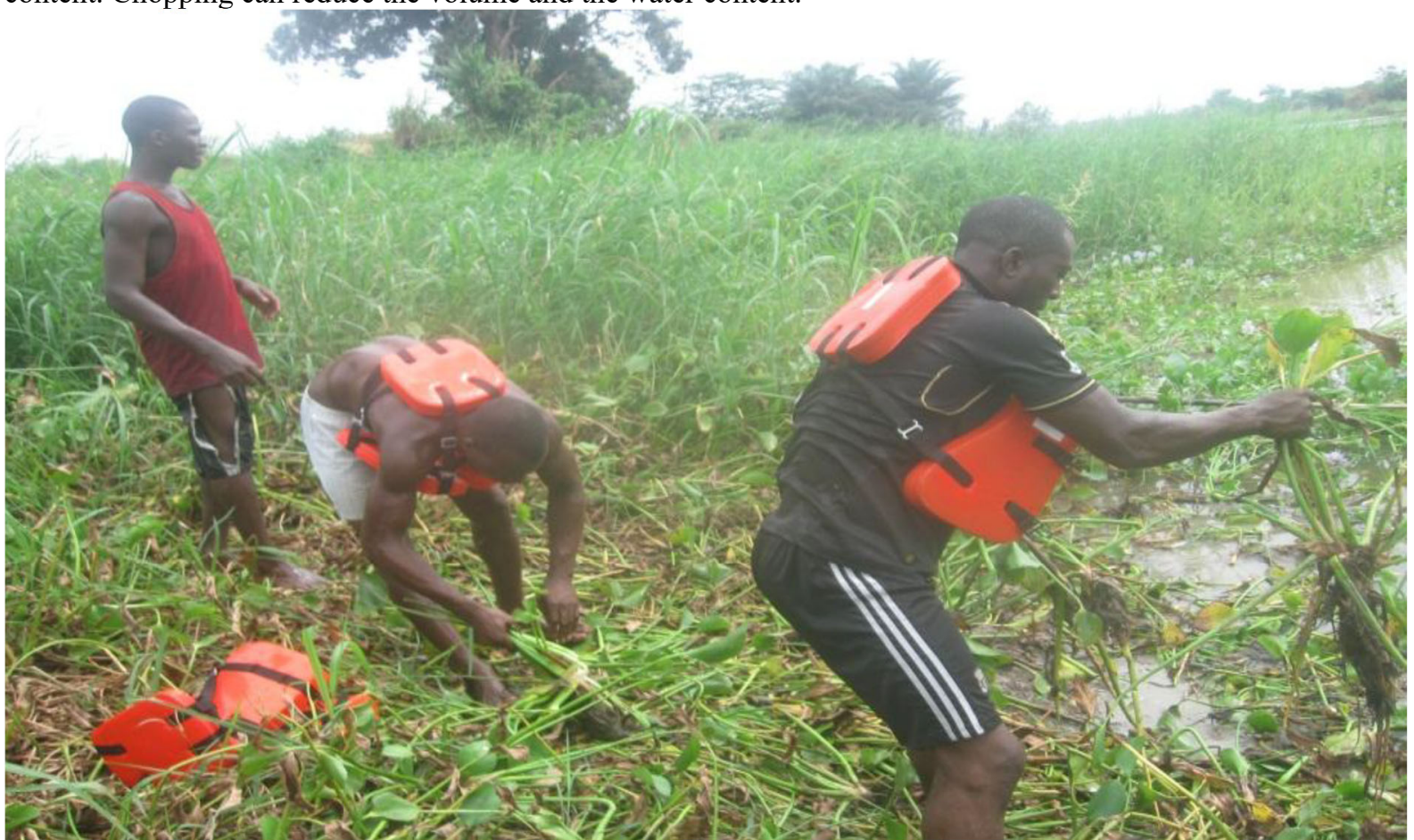

Figure 3. Manual Uprooting of Water Hyacinth (Source: Elenwo and Akankali, 2019).

\subsubsection{Biological Control of Water Hyacinth}

Biological control was generally considered the most cost effective and environment friendly control method for aquatic weeds in general and water hyacinth specifically. The types of organisms that can be deployed as biological control agent range from the very minutes, such as microbes like fungi, through weevils, to macro 
vertebrates/invertebrates such as herbivorous species like the Neochetina species.

About eight arthropod agents (Neochetina brunchi, Neochetina eichhorniae, Niphograpta albiguttalis, Orthogalumna terebrantis, Eccritotarsus catarinensis, Xubida infusellus, Cornops aquaticum and Thrypticus spp.) released worldwide for the control of Water Hyacinth (Julien et al., 1998; Tipping et al., 2014). Among these arthropod, two weevils, Neochetina eichhorniae and Neochetina bruchi, are the most effective in controlling the weed (Center et al., 1999; Center and Van, 1989; DeLoach and Cordo, 1976). N. bruchi and N. eichhorniae have been released on water hyacinth in 30 and 27 countries, respectively (Center et al., 2002). These weevils are host specific and successful biological agents used for the control of water hyacinth. Thus, based on their damage potential and difference in rate of population growth, it is concluded that Neochetina bruchi could be considered as a promising candidate for biological control of water hyacinth under Ethiopian conditions (Firehun et al., 2015). These arthropods involved in biological control of water hyacinth also facilitate the transfer and ingress of deleterious microorganisms (both fungi and bacteria) associated with the weevils into the plant tissues (Van et al., 2010).
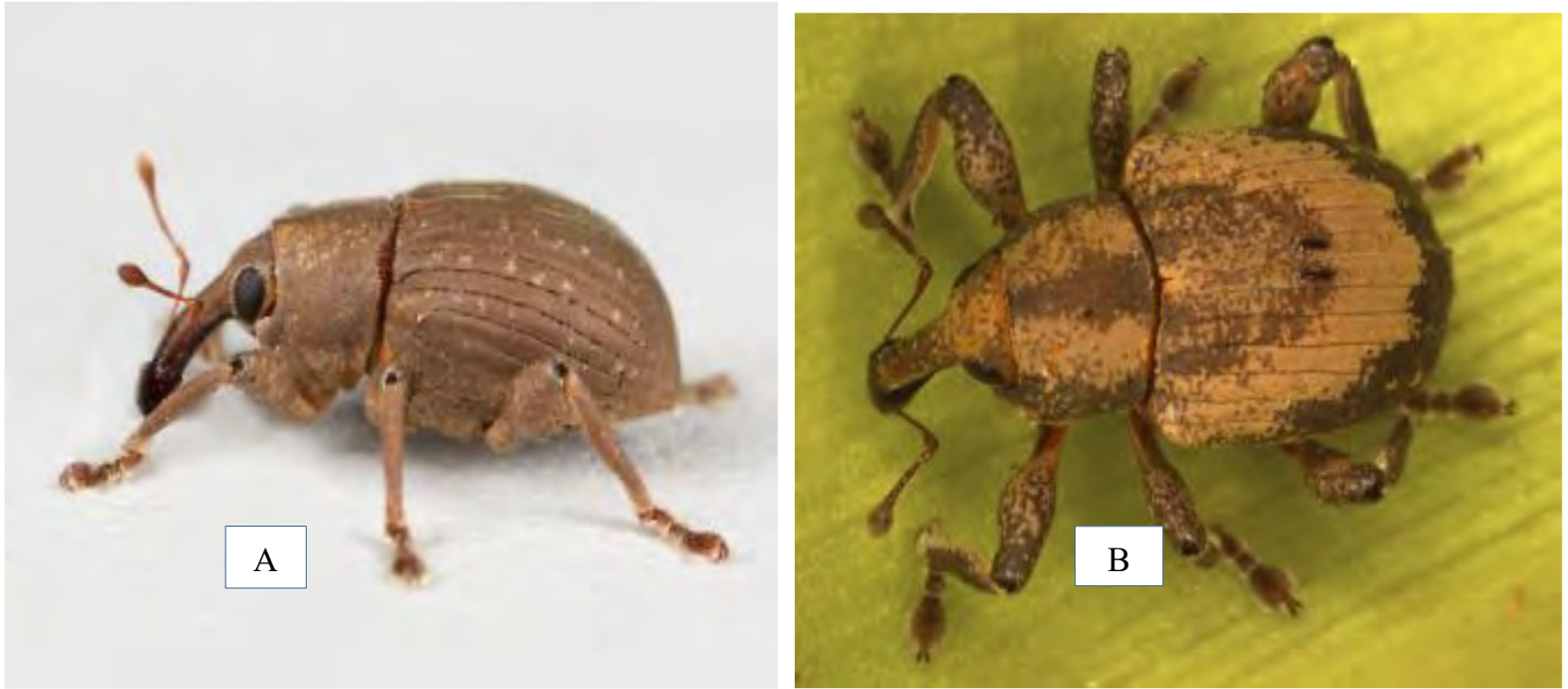

Figure 4. Biological control agents A) Neochetina eichornia, B) Neochetina bruchi

Several highly virulent fungal pathogens of water hyacinth occur in different parts of the world. Among them are Acremonium zonatum, Alternaria alternata, Alternaria eichhorniae, Bipolaris/Helminthosporium spp., Cercospora piaropi, Cercospora rodmanii, Myrothecium roridum, Rhizoctonia solani, and Uredo eichhorniae. However, only Cercospora rodmanii and Alternaria eichhorniae have been studied to a significant extent. Among the 9 pathogens, 3 pathogens Cercospora rodmanii, Alternaria alternata and Alternaria eichhorniae are recognized as potential mycoherbicide agents in controlling water hyacinth (Dagno et al., 2012). Rhizoctonia disease caused by Rhizoctonia solani is usually very aggressive and destructive, capable of killing large amounts of water hyacinth biomass in a rapid and complete manner in many countries such as United States, Brazil, Mexico, Panama, Puerto Rico, India, Malaysia and Indonesia (Shabana et al., 1995). Aqueous leachate of Lantana camara was found killing water hyacinth (Saxena 2000). Biological control was considered as the only effective, permanent and environmentally friendly methods.

\subsubsection{Chemical Control}

The highest economic efficiency is achieved with chemicals that are able to eradicate the weed within the required time period at the least possible cost. Mailu (2001) reported that the best chemical control is achieved with 2, 4-D dimethyl amine $58 \%\left(4 \mathrm{~kg} \mathrm{ha}^{-1}\right)$ and that the cost of removal by this herbicide was $61 \%$ less than that of manual weeding. Adekoya 2000 concluded that glyphosphate is safe (with no adverse effect on fish population) and cost effective in Water hyacinth management when properly used under specialist supervision. Similarly, Agidie 2018 concluded that Glyphosate and acetic acid are effective in controlling water hyacinth at shade level.

However water hyacinth control by herbicides application is quite hazardous to the environment due to toxicity effects from the residual effects of the herbicides and also the adverse effects on water quality due to putrefaction of the dead weed leading to eutrophication problems (Chikwenhere and Forno, 1991). Applications of herbicides cause depletion of dissolved oxygen which leads to massive fish and other aquatic resources of economic importance mortalities (Caunter and Seeni, 1991). 


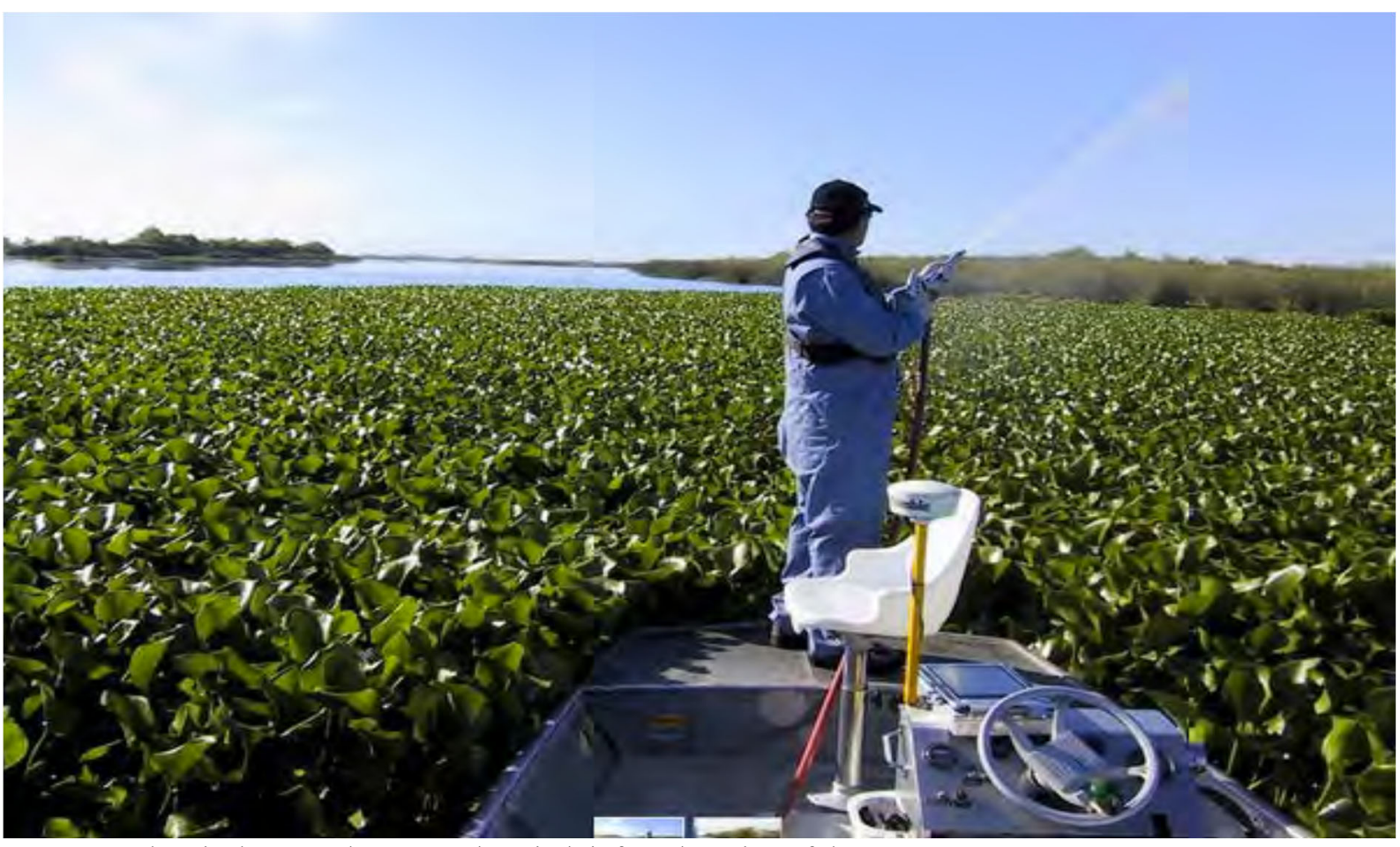

Figure 5. Chemical Sprayed on water hyacinth infested section of the Waterways.

\subsubsection{Integrated Water Hyacinth Management}

The research conducted at Wonji-Shoa Sugar Factory indicated that an integrated use of herbicidal and mechanical control measures are resulted in better management of the weed than physical control measures especially in the reservoirs, irrigation supplies and drainage systems (Dula et al., 2008). However, the control was not possible to ensure these results; because of infestation from upstream water bodies remained contaminated with this noxious aquatic weed.

\section{SUMMARY AND CONCLUSION}

Water hyacinth is one of the 10 world's worst invasive weeds which invade water bodies of many countries in the world. It is an alien, floating water weed that has spread throughout vital freshwater bodies and wetlands. It is native to South America and extremely invaded many tropical and subtropical countries of all the continents. When the weed is away from its center of origin, it is also away from its natural enemies and has the capacity to quickly multiply and spreads over the continents.

The weed poses serious socioeconomic and environmental problems for millions of people in riparian communities. It obstructs electricity generation, irrigation, navigation, and fishing; clogs waterways and ports; cause the destruction of the flora and fauna underneath; facilitates proliferation of bilharzia; habitat for malaria transmitting mosquitoes; and deteriorates the quality of drinking, cooking, and washing water.

Control of water hyacinth using manual, mechanical removal, chemical, biological or integrated weed management methods has been mostly employed globally. Manual and mechanical removal of water hyacinth in small areas at early time is effective in controlling the weed for short period of time. Use of biological control agents; arthropods (Neochetina brunchi, Neochetina eichhorniae, Niphograpta albiguttalis and Orthogalumna terebrantis) and parasitic fungi (Cercospora rodmanii, Alternaria alternata and Alternaria eichhorniae) play a role in controlling the weed. In addition Chemical control with 2, 4-D dimethyl amine, glyphosphate and acetic acid are effective to control water hyacinth in extreme cases. Integrated use of herbicidal and mechanical control measures is effective in control, economically safe and environmentally friendly than a single control measures.

\section{REFERENCES}

Adekoya B (2000). Chemical control of water hyacinth(Eichhornia crassipes at Ere, Ogun State, Nigeria: Implications for Aquatic and Terrestial Biodiversity Conservation.Paper presented at the International conference on water hyacinth, held at New Bussa, Nigeria.

Agidie A, Sahle S, Admas A and Alebachew M (2018) Controlling Water Hyacinth, Eichhorni acrassipes (Mart.) Solms Using Some Selected Eco-Friendly Chemicals. J Aquac Res Development. 9: 521.

Caunter I and Seeni M (1991). The effect of Neochetina eichhorniae and Myrothecium roridum alone and in combination for the initial biological control of water hyacinth. J. Plant. Prot. Tropics. 7: 133-140. 
Center T and Van T (1989). Alteration of water hyacinth (Eichhornia crassipes) leaf dynamics and phytochemistry by insect damage and plant density. Aquat. Bot. 35:181-195.

Center T, Dray J, Jubinsky F and Grodowitz M (1999). Biological control of water hyacinth under conditions of maintenance management: can herbicides and insects be integrated? Environ. Manage. 23: 241-256.

Center T, Hill M, Cordo H and Julien M (2002). Water hyacinth. In: Van Driesche R, Lyon S, Lossey B, Hoddle $\mathrm{M}$ and Reardon R (Eds.), Biological Control of Invasive Plants in the Eastern United States. USDA Forest Service, Morgantown, WV, pp. 41-64.

Chikwenhere G and Forno I (1991). Introduction of Neohydronomus affinis for Biological control of Pistia stratiotes in Zimbabwe. J. Aquat. Plant Manage. 29: 53-55.

Dagno K, Lahlali R, Diourté M and Jijakli H (2012). Fungi occurring on waterhyacinth (Eichhornia crassipes (Martius) Solms) in Niger River in Mali and their evaluation as mycoherbicides. Journal of Aquatic Plant Management. 50:25-32.

DeLoach C and Cordo H (1976). Ecological studies of Neochetina bruchi and N. eichhorniae on water hyacinth in Argentina. J. Aquat. Plant Manage. 14: 53-59.

Dula A Taye T and Firehun Y (2008). Efficacy of integrated water hyacinth (Eichhornia crassipes) management strategies at Wonji-Shoa sugar factory. Eth. J. Weed Manage. 2: 45-58.

Elenwo E and Akankali J (2019). Review of Conventional Methods of Water Hyacinth Controls and Option for Niger Delta Region Nigeria: International Journal of Advances in Scientific Research and Reviews. 4(1):7490.

Firehun Y, Struik P, Lantinga E and Taye T (2015). Adaptability of two weevils (Neochetina bruchi and Neochetina eichhorniae) with potential to control water hyacinth in the Rift Valley of Ethiopia. Crop Protection. 76:75-82.

Hill G, Waage J and Phiri G (1997). The water hyacinth problem in tropical Africa. In International Water Hyacinth Consortium. Washington D.C U.S Department of Agriculture.

Julien M (2001). Biological control of water hyacinth with arthropods: a review to 2000. Biological and integrated control of water hyacinth Eichhornia crassipes. In: Julien M, Hill M and Jianqing D (Eds.), Proceedings of the Second Meeting of Global Working Group for the Biological and Integrated Control of Water Hyacinth, ACIAR Proceeding Number 102. Beijing, China, 9-12 October 2000, pp. 120-122.

Julien M and Griffiths M (1998). Biological Control of Weeds: A World Catalogue of Agents and their Target Weeds. 4th edition. ABI Publishing, Oxford, pp. 90-96.

Mailu F (2001). Biological control of aquatic weeds. UNEP Res. And Prourement Series 7 Nairobi, Kenya, pp. $320-323$

Navarro L and Phiri G (2000). Water hyacinth in Africa and the Middle East: A survey of problems and solutions. Idrc.

Patel S (2012). Threats, management and envisaged utilizations of aquatic weed Eichhornia crassipes: an overview. Reviews in Environmental Science and Bio/Technology. 11(3): 249-259.

Penfound W and Earle T (1948). The biology of the water hyacinth. Ecological Monographs, pp.447-472.

Saxena M (2000). Aqueous leachate of Lantana camara kills water hyacinth. Journal of Chemical Ecology $13: 2435-2447$.

Shabana Y, Charudattan R and Elwakil M (1995). Identification, pathogenicity, and safety of Alternaria eichhorniae from Egypt as a bioherbicide agent for waterhyacinth. Biological Control. 5(2):123-135.

Téllez T, López E, Granado G, Pérez E, López R and Guzmán J (2008). The water hyacinth, Eichhornia crassipes: an invasive plant in the Guadiana River Basin (Spain). Aquatic Invasions. 3(1): $42-53$.

Tipping P, Sosa A, Pokomy N, Foley J, Schmitz D, Lane S, Rodgers L, McCloud L, Livingston-Way P and Nicholas G (2014). Release and establishment of Megamelus scutellaris (Hemiptera: Delphacidae) on water hyacinth. Fla. Entomol. 97 (2): 804-806.

Uka, U.N., 2008. Chemical control method as a management approach to water hyacinth infestation in Nigeria. Zonas Áridas. 12(1):184-190.

Van T, Ajuonu R, Schade V, Neuenschwander V, Adit Ä and Lomer C (2010). Importation, releases, and establishment of Neochetina spp. (Col,:Curculionidae) for the biological control of water hyacinth, Eichhornia crassipes (Lil.: Pontederiaceae), in Benin,West Africa. Entomophaga, 39: 179-188.

WHO (World Health Organization) (1997). Report on Problems and Environmental Impacts of Water Hyacinth. Page 5 in: Proc. 2nd Workshop on Water Hyacinth, Kampala, Uganda. 